\title{
POSTLEPIDAPEDON QUINTUM N. SP. (DIGENEA: LEPOCREADIIDAE) FROM THE BASTARD TRUMPETER LATRIDOPSIS FORSTERI (PERCIFORMES: LATRIDAE) OFF THE COAST OF NORTHERN TASMANIA
}

\author{
by Rodney A. Bray \& Thomas H. Cribb \\ (with one text figure)
}

\begin{abstract}
BraY, R.A. \& CRIB B, T.H., 2001 (31:xii): Postlepidapedon quintumn. sp. (Digenea: Lepocreadiidae) from the bastard trumpeter Latridopsis forsteri (Perciformes: Latridae) off the coast of northern Tasmania. Pap. Proc. R. Soc. Tasm. 135: 21-23.

https://doi.org/10.26749/rstpp.135.21 ISSN 0080-4703. Department of Zoology, Natural History Museum, Cromwell Road, London SW7 5BD, UK (RAB); Department of Microbiology and Parasitology, The University of Queensland, Brisbane, Queensland, Australia 4072 (THC).
\end{abstract}

\begin{abstract}
The new lepocreadiid species, Postlepidapedon quintum, is erected for worms recovered from the perciform fish Latridopsis forsteri off the coast of northern Tasmania. It is distinguished from its congeners by the vitelline extent and the shape and thickness of the wall of the internal seminal vesicle. A key to the genus Postlepidapedon is given. P. quintum is likely to be endemic to southern Australia and New Zealand, as is its host.
\end{abstract}

Key Words: Postlepidapedon, Latridopsis, Digenea, Lepocreadiidae, Tasmania.

\section{INTRODUCTION}

Postlepidapedon Zdzitowiecki, 1993 was erected by Zdzitowiecki (1993) to accommodate his species Neolepidapedon opisthobifurcatus Zdzitowiecki, 1990 from the gadiform fish Muraenolepis microps off South Georgia (Zdzitowiecki 1990). This species had an "Opechona-type" cirrus-sac (as defined by Bray \& Gibson 1989), but with an elongate, rather than oval, internal seminal vesicle, and the intestinal bifurcation displaced posteriorly at about the level of the posterior margin of the ventral sucker (Zdzitowiecki 1990; Zdzitowiecki \& Cielecka 1997). Bray et al. (1997) placed three further species in the genus $-P$. secundum (Durio \& Manter, 1968), P. spissum Bray, Cribb \& Barker, 1997 and P. uberis Bray, Cribb \& Barker, 1997 - and gave a key to these four species. In this paper we present a description of a further species of Postlepidapedon.

We are aware of only two previous records of digeneans from Latridopsis forsteri, a perciform teleost endemic to southern Australia and New Zealand (Froese \& Pauly 2001). These records are of the opecoelid Opecoelus tasmanicus Crowcroft, 1947 from the Hobart fish market, Tasmania (Crowcroft 1947), and the lepocreadiid Scaphatrema nemadactyli (Kurochkin \& Korotaeva, 1972) from the Great Australian Bight/Tasman Sea area (Kurochkin \& Korotaeva 1972).

\section{MATERIALS AND METHODS}

Digeneans collected from freshly killed fish were fixed by being pipetted into nearly boiling saline and immediately preserved in formalin or $70 \%$ ethanol. Whole-mounts were stained with Mayer's haematoxylin, cleared in methyl salicylate and mounted in Canada balsam. Measurements were made through a drawing tube on an Olympus BH-2 microscope, using a Digicad Plus digitising tablet and Carl Zeiss KS100 software adapted by Imaging Associates, and are quoted in micrometres, averages are in parentheses. The following abbreviations are used: $\mathrm{BMNH}$, the British Museum (Natural History) collection at The Natural History
Museum, London, UK; QM, Queensland Museum collection, Brisbane, Australia.

\section{RESULTS}

Family Lepocreadiidae Odhner, 1905

Family Lepocreadiinae Odhner, 1905

Genus Postlepidapedon Zdzitowiecki, 1993

Postlepidapedon quintum n. sp. (Fig. 1A, B)

\section{Material studied}

Ex Latridopsis forsteri (Castelnau) (Latridae). Intestine. Off Stanley, Tasmania (4046'S, $145^{\circ} 20^{\prime} \mathrm{E}$, Dec., 1999). Prevalence $75 \%$ (six of eight hosts infected). QM holotype G217784, paratypes G217785-217798, BMNH paratypes 2001.6.1.1-8.

\section{Description}

Based on 22 whole-mounts. Body with narrow, tapering forebody, wider hindbody, 773-1634 × 237-443 (1088 $\times$ 342 ); width 26-40 (32) \% of length (fig. 1A). Tegument spinose; spines becoming scarcer posteriorly, reach to close to posterior extremity. Eye-spot pigment sparse, scattered in forebody, or not seen. Pre-oral lobe short, 1-16 (6). Oral sucker subglobular, subterminal, 90-172 ×91-179 (123× 132). Ventral sucker rounded, pre-equatorial, 104-205 $\times$ 114-218 (152 × 160). Forebody 213-498 (299) long, 24-31 (27) \% of length. Sucker-width ratio 1:1.11-1.56 (1.22). Prepharynx short, but distinct, partly in posterior concavity of oral sucker, thick-walled, 10-50 (26) long. Pharynx subglobular, 59-128 ×57-113 $(82 \times 85)$. Pharynx to oral sucker width ratio 1:1.20-1.64 (1.55). Oesophagus distinct, 30-87 (54) long. Intestinal bifurcation more or less dorsal to anterior part of ventral sucker. Caeca blind, reach to within 21-117 (53) of posterior extremity.

Testes 2, tandem, oval, entire, contiguous, usually contiguous with ovary, occasionally slightly separated by up to 21 ; anterior $87-159 \times 106-168(113 \times 136)$, posterior 


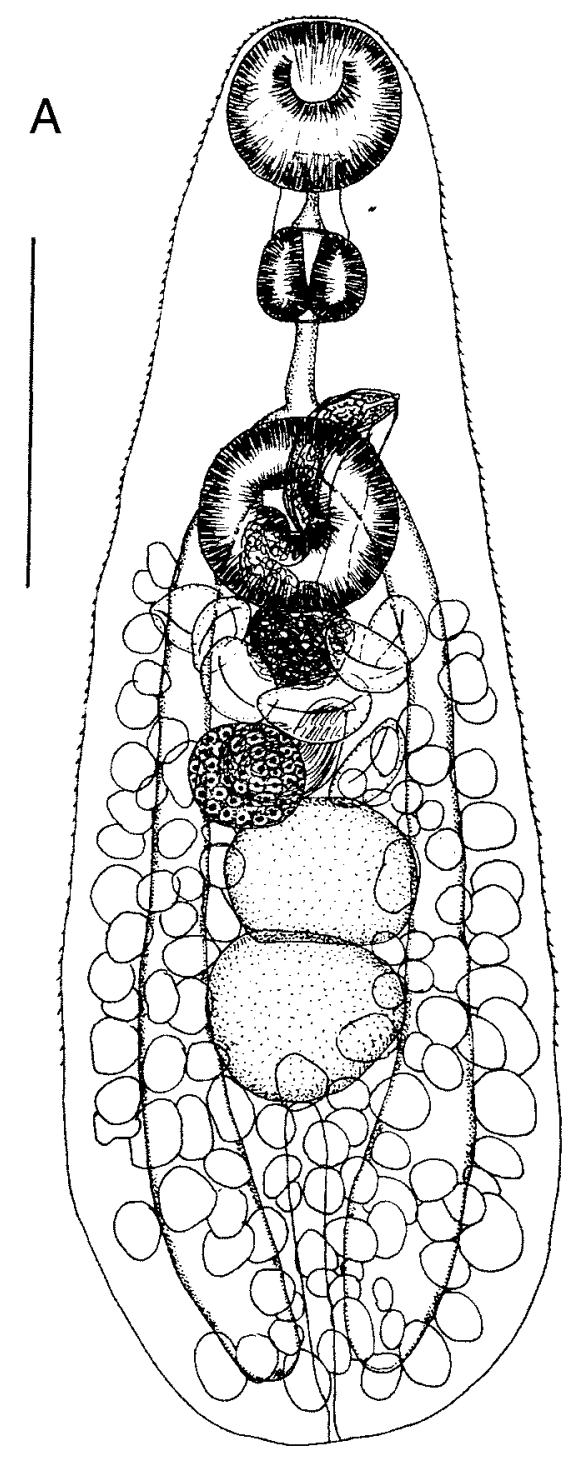

101-204 × 110-187 $(133 \times 135)$. Post-testicular region 161-390 (255) long, 19-27 (23) \% of body length. External seminal vesicle saccular, reaches 42-127 (77) into hindbody, 49-140 (87) \% of ventral sucker to ovary distance. Cirrussac oval, slightly curved, overlaps to about middle of ventral sucker, wall fairly thick, 89-197 × 27-60 (119 × 36) (fig. 1B). Internal seminal vesicle rectilinear, fusiform, fairly thick-walled. Pars prostatica vesicular, subglobular, lined with anuclear cell-like bodies, towards distal end of cirrussac. Ejaculatory duct short, wide. Everted cirrus not seen. Genital atrium distinct. Genital pore sinistral, about midway between median line and body margin, just pre-bifurcal in posterior forebody.

Ovary subglobular, entire, usually contiguous with anterior testis, sinistral, 51-140 × 44-125 (83 × 79); 59128 (90) from ventral sucker. Seminal receptacle canalicular, saccular, mainly dorsal to ovary. Mehlis' gland dorso-median to ovary. Laurer's canal opens dorsally to left caecum at level of posterior part of uterus. Uterus pretesticular, sinistral to ovary and between ovary and about mid-ventral sucker level. Eggs not numerous, tanned, operculate, 59-92 $\times$ $24-53(76 \times 40)$, decrease slightly in size with increase in degree of tanning. Metraterm muscular, commences about

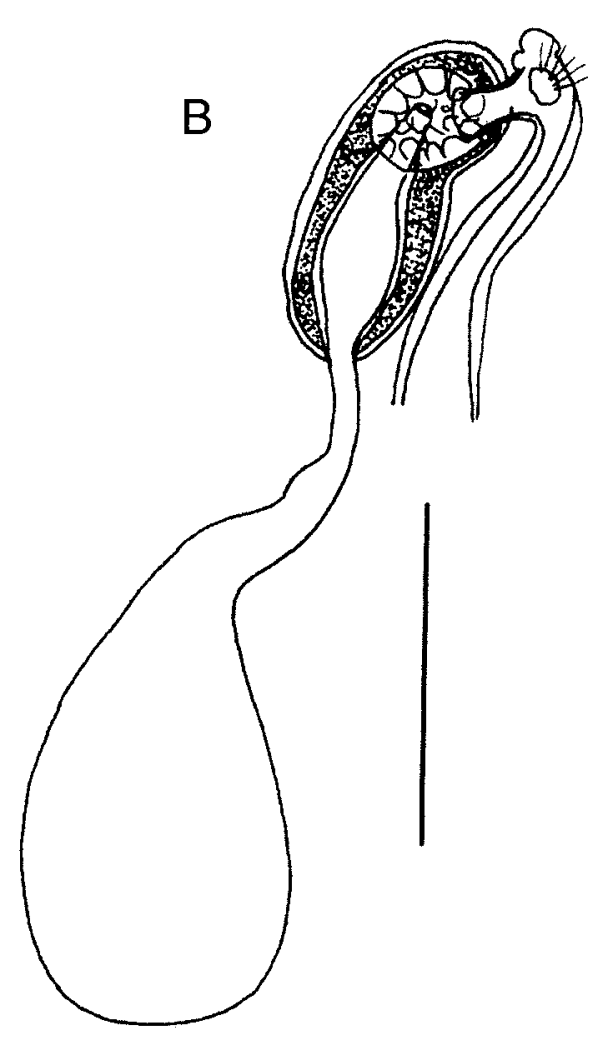

Fig. 1 - Postlepidapedon quintum n. sp. (A) Ventral view of holotype. Scale bar $=200 \mu \mathrm{m}$. (B) Terminal genitalia. Scale bar $=100 \mu \mathrm{m}$.

mid-ventral sucker level. Vitellarium follicular; fields reach from level of ventral sucker or occasionally just posterior $(<15)$ to posterior extremity; lateral fields lie ventral, lateral and dorsal to caeca, encroaching only slightly over gonads, confluent dorsally and ventrally in post-testicular region.

Excretory pore terminal. Excretory vesicle I-shaped, reaches just to posterior margin of posterior testis.

\section{DISCUSSION}

This new species fits comfortably into the small genus Postlepidapedon Zdzitowiecki, 1993, which is characterised mainly by the relatively narrow internal seminal vesicle (as opposed to the oval to subglobular internal seminal vesicle found in most lepocreadiines) and the intestinal bifurcation being dorsal to the ventral sucker. Other species of the genus tend to have the intestinal bifurcation at a level relatively further posterior than $P$. quintum. Nevertheless, the five species now recognised are all similar. $P$. quintum and $P$. opisthobifurcatum both have their vitellarium reaching to, or almost to, the ventral sucker, whilst the other three species have their vitellarium restricted to well within the hindbody. 
The intestinal bifurcation of $P$. quintum is slightly more anterior than that found in $P$. opisthobifurcatum and the wall of the internal seminal vesicle distinctly thicker. The internal seminal vesicle is more or less rectilinear in $P$. quintum, $P$. opisthobifurcatum and $P$. spissum, whereas it is thin-walled and coiled in P. uberis and P. secundum.

Postlepidapedon is now known from gadiforms of the families Muraenolepididae and Macrouridae and perciforms of the families Labridae and Latridae. It is restricted to the Southern Hemisphere, i.e. from the waters off Australia, New Caledonia and the Antarctic. P. quintum adds a further species to the endemic fauna which make up some $85 \%$ of the fauna in the waters of southern and southwestern Australia (Bray \& Cribb 2001; Bray et al. 1999).

\section{ACKNOWLEDGEMENTS}

We are grateful to Sylvie Pichelin for helping THC in the collection of this material and Trudy Wright for processing the material. David Gibson kindly read the manuscript.

\section{REFERENCES}

BRAY, R.A. \& CRIBb, T.H., 2001: Amphicreadium gen. n. (Digenea: Lepocreadiidae) from monacanthid fishes (Tetraodontiformes) from the coast of northern Tasmania. Syst. Parasitol. 49: 205-209.
BRAY, R.A. \& GibSON, D.I., 1989: The Lepocreadiidae (Digenea) of fishes from the north-east Atlantic: review of the genus Neolepidapedon Manter 1954, with a description of $N$. smithi n. sp. Syst. Parasitol. 13: 11-23.

Bray, R.A., Cribb, T.H. \& Barker, S.C., 1997: Postlepidapedon Zdzitowiecki, 1993 and Gibsonivermis n. g. (Digenea: Lepocreadiidae) from fishes of the southern Great Barrier Reef, Australia, and their relationship to Intusatrium Durio \& Manter, 1968. Syst. Parasitol. 36: 143-155.

Bray, R.A., Cribb, T.H. \& Pichelin, S.P., 1999: Two new species of lepidapedines (Digenea, Lepocreadiidae) from the King George whiting Sillaginodes punctata (Perciformes, Sillaginidae) from off Kangaroo Island, South Australia. Acta Parasitol. 44: 108-114.

Crowcroft, P.W., 1947: Some digenetic trematodes from fishes of shallow Tasmanian waters. Pap. Proc. R. Soc. Tasm. 81: 5-25.

Froese, R. \& Pauly, D., 2001: FIShbASE. World Wide Web electronic publication. www.fishbase.org.

Kurochin, Y. \& Korotaeva, V.D., 1972: [Trematodes of the genus Multitestis Manter, 1931 (Fam. Lepocreadiidae) from marine fishes of Australia and New Zealand]. Parazitologiya 6: 75-78. (In Russian.)

ZDziTOWIECKI, K., 1990: Little known and new Antarctic Digenea species of the genera Neolepidapedon and Lepidapedon (Lepocreadiidae). Acta Parasitol. 35: 19-30.

ZDzitowiecki, K., 1993: A contribution to the morphology of the Antarctic fish lepocreadiid digeneans, with a description of a new genus. Acta Parasitol. 38: 109-112.

ZDZITOWIECKI, K. \& CIELECKA, D., 1997: Digenea of fishes of the Weddell Sea. I. Parasites of Macrourus whitsoni (Gadiformes, Macrouridae). Acta Parasitol. 42: 23-30.

(accepted 10 May 2001) 